\title{
SPECTROPHOTOMETRIC STUDIES ON THE INTERACTION OF YEAST RNA WITH CRYSTAL VIOLET AND ITS ANALYTICAL APPLICATION
}

\author{
NA ZHAO ${ }^{1}$, MANXIA WANG ${ }^{2}$, XUELIANG NIU' ${ }^{1}$, WEI SUN ${ }^{1 *}$ AND KUI JIAO ${ }^{1}$
}

\begin{abstract}
1.College of Chemistry and Molecular Engineering, Qingdao University of Science and Technology, Qingdao 266042, P. R. China; 2. Shandong Entry-Exit Inspection and Quarantine Bureau of People' s Republic of China, Qingdao 266002, P. R. China.
\end{abstract}

(Received: October 2, 2007 - Accepted: July 14, 2008)

\begin{abstract}
The interaction of crystal violet (CV) with yeast RNA (yRNA) was studied by UV-Vis absorption spectrophotometric method in this paper and further a simple spectrophotometric method for the yRNA determination was proposed. At a pH 4.0 Britton-Robinson (B-R) buffer solution, $\mathrm{CV}$ had a maximum absorption peak at $590 \mathrm{~nm}$, which was greatly decreased by the addition of yRNA. The conditions of CV interacted with yRNA were carefully investigated. Under the optimal conditions the decrease of absorbance value was proportional to the concentration of yRNA in the range from $3.33 \times 10^{-6}$ to $1.67 \times 10^{-5} \mathrm{~mol} \mathrm{\textrm {L } ^ { - 1 }}$ when $2.0 \times 10^{-5}$ mol $\mathrm{L}^{-1} \mathrm{CV}$ was employed. The detection limit was calculated as $5.34 \times 10^{-7} \mathrm{~mol} \mathrm{~L}^{-1}(3 \sigma)$ and different samples were determined satisfactorily. The binding number and the binding constant of CV with yRNA were calculated by spectrophotometric data with the results as 1 and $1.69 \times 10^{5} \mathrm{~L} \mathrm{~mol}{ }^{-1}$, respectively. The reaction mechanism was discussed with the electrostatic attraction led to molecular association of yRNA with CV.
\end{abstract}

Keywords: crystal violet, yeast RNA, UV-Vis spectrophotometry, interaction

\section{INTRODUCTION}

Nucleic acids (NAs) are very important for their specific functions in the life science. The quantitative determination of NAs is of great importance for its wide use in bioanalytical chemistry and clinical test. Many methods have been proposed for the NAs determination including UV-Vis spectrophotometry, ${ }^{1,2}$ fluorescence, ${ }^{3,4}$ light-scattering technique ${ }^{5,6}$ and electrochemical methods. ${ }^{7,8}$ Since the natural spectroscopic response of NAs is not very sensitive, most of the detection methods are based on the interaction of various molecules with NAs.

Spectrophotometry has been widely used to study the interaction of NAs with numerous molecules such as metal chelates, dyes and drugs in solution.9${ }^{11}$ But most of them are focused on the investigation with deoxyribonucleic acid (DNA) for its importance in related to the replication and transcription, mutation of genes, action mechanisms of some DNA-related diseases and DNAtargeted drugs, specific sequence gene detection and so on. Compared with DNA, the reports on the interaction with ribonucleic acid (RNA) is seldom to our knowledge. RNA is also important in the process of transcription and some of the gene information is concerned with RNA. ${ }^{12}$ More evidences indicate that proteins may take advantage of the conformational polymorphism in the RNA backbone to recognize the specific binding sites on the macromolecule. Some transition metal chelates such as rhodium (III) phenanthroline, ruthenium (II) polypyridine, zinc (II) imidazole etc. have been served as the selective probe for RNA recognition and hydrolysis. The interaction of these molecules with RNA can be used to better understand the structure and nature of RNA. ${ }^{13-17}$ Recently, Sun et al. applied an electrochemical method to investigate the interaction between pyronine B with RNA. ${ }^{18}$ So it is essential to establish the quantitative method for RNA determination and the results can be used as a reference for measurements of other components in biological system.

In this paper, crystal violet (CV) was selected as the spectrophotometric probe to determine yeast RNA (yRNA). Yeast RNA was extracted from yeast cell and often used as a model for RNA investigation, while CV is a triphenylmethane cationic dye with low cost and often used as biological stains with its structure shown in Figure 1. The spectrophotometric behaviors of crystal violet (CV) in the absence and presence of yeast RNA (yRNA) in buffer solution was examined in this paper. In $\mathrm{pH}$ 4.0 Britton-Robinson (B-R) buffer solution, the interaction of yRNA with $\mathrm{CV}$ resulted in the changes of UV-Vis absorbance curve, which could be further used for yRNA detection. Under the optimal conditions, the binding number and the binding constant were calculated by the spectrophotometric data and the reaction mechanism was further discussed.

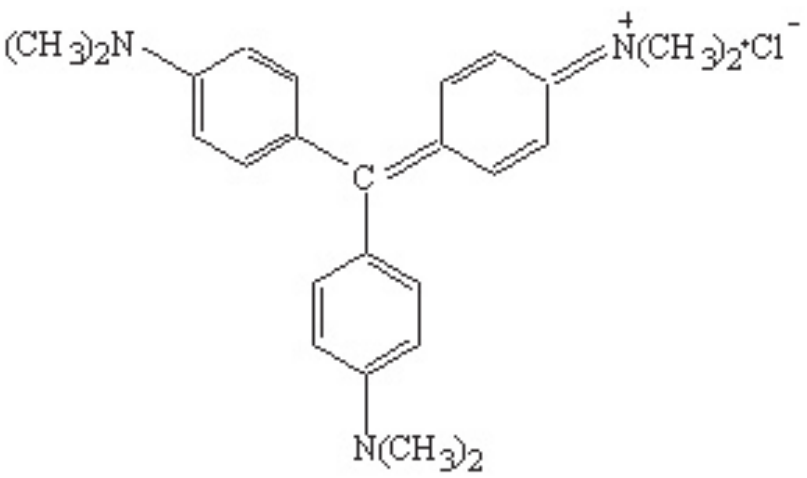

Fig. 1. The molecular structure of crystal violet

\section{EXPERIMENTAL}

\section{Apparatus and reagents}

The experiments were carried out on a $721 \mathrm{E}$ UV-Vis spectrophotometer (Shanghai Spectra Instrumental Company) and a Cary model 50 probe spectrophotometer (Varian, Australia). The $\mathrm{pH}$ values were measured with a pH-25 acidimeter (Shanghai Leici Instrument Factory, China).

Yeast ribonucleic acid (yRNA, Tianjin Damao Chemical Reagents Company, China) was used as received without further purification. A 3.33 $\times 10^{-3} \mathrm{~mol} \mathrm{~L}^{-1}$ stock solution of yRNA (the mole of yRNA was defined as that of a repetitive disaccharide unit of yRNA and used as 300) was prepared by dissolving it in double-distilled water and stored at $4^{\circ} \mathrm{C}$. The working solutions were obtained by diluting the stock solution with water before use. The sample of Instant Dry Yeast was purchased from Hubei Angel Yeast Co. Ltd (2007$11-13 w)$. The concentration of yRNA was determined spectrophotometrically according to the absorbance at $260 \mathrm{~nm}$ after establishing that the absorbance ratio of $\mathrm{A}_{260} / \mathrm{A}_{280}$ was in the range of 1.80-2.00 for RNA, which indicated that the yRNA was free of protein. The molar extinction coefficient $\left(\varepsilon_{\mathrm{pN}}\right)$ value was taken as $7800 \mathrm{~L} \cdot \mathrm{mol}^{-1} \cdot \mathrm{cm}^{-1}$. A $1.0 \times 10^{-3} \mathrm{~mol} \mathrm{~L}^{-1}$ crystal violet $(\mathrm{CV}$, Shanghai Yuanhang Chemical Factory, China) solution was prepared by dissolving $0.0408 \mathrm{~g} \mathrm{CV}$ into water and diluted to $100 \mathrm{~mL} .0 .2 \mathrm{~mol} \mathrm{~L}^{-1}$ Britton-Robinson (B-R) buffer solution was used to control the acidity of the interaction solution. All the chemicals used were of analytical reagents grade and double-distilled water was used throughout.

\section{Procedure}

Into a $10 \mathrm{~mL}$ calibrated tube $0.2 \mathrm{~mL}$ of $1.0 \times 10^{-3} \mathrm{~mol} \mathrm{~L}^{-1} \mathrm{CV}$ solution, $2.0 \mathrm{~mL}$ of $\mathrm{pH} 4.0 \mathrm{~B}-\mathrm{R}$ buffer solution and an appropriate amount of standard 
yRNA solution or yeast samples were added in sequences. The mixture was diluted to the scale with water and shaken homogeneously, then stood for reaction at $25^{\circ} \mathrm{C}$ for $20 \mathrm{~min}$. The spectra or absorbance of the mixed solution were measured with the reference to water and the absorbance value at 590 $\mathrm{nm}$ was recorded (A). Under the same conditions, the absorbance value of the solution $\left(\mathrm{A}_{0}\right)$ without the addition of yRNA was obtained. The difference of the absorbance $\left(\Delta \mathrm{A}=\mathrm{A}_{0}-\mathrm{A}\right)$ was used for the determination of the yRNA concentration.

\section{RESULTS AND DISCUSSION}

\section{Feature of UV-Vis absorption spectra}

Figure 2 showed the UV-Vis absorption spectra of $\mathrm{CV}$ and its mixture with yRNA. In $\mathrm{pH} 4.0 \mathrm{~B}-\mathrm{R}$ buffer solution, $\mathrm{CV}$ had a maximum absorption band at $590 \mathrm{~nm}$ (curve 2) and yRNA showed no absorption in the selected wavelength range (curve 1). When yRNA solution was added into CV solution, a significant hypochromic effect was observed without the shift of wavelength (curve 3). The results indicated that an interaction was took place in the mixture solution. Based on the decrease of absorbance value, a simple and sensitive spectrophotometric method was further established for yRNA determination.

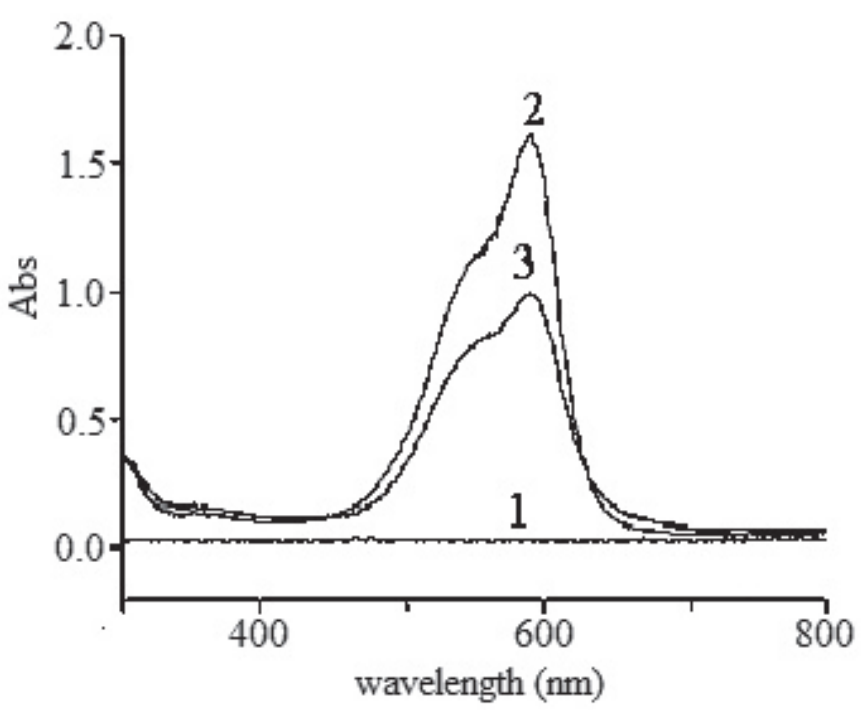

Fig. 2: UV-Vis absorption spectra of crystal violet with yRNA

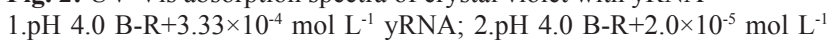
$\mathrm{CV} ; 3.2+3.33 \times 10^{-4} \mathrm{~mol} \mathrm{~L}^{-1}$ yRNA

\section{Optimization of general procedures}

\section{Effect of buffer pH}

The influence of buffer $\mathrm{pH}$ on the binding reaction was studied and the results were shown in Figure 3. In the $\mathrm{pH}$ range from 3.0 to 8.0, the value of $\Delta \mathrm{A}$ reached its maximum at $\mathrm{pH} 4.0$, hence this $\mathrm{pH}$ was selected for the assay. The amount of $0.2 \mathrm{~mol} \mathrm{~L}^{-1} \mathrm{~B}-\mathrm{R}$ buffer was selected with the result as $1.0 \mathrm{~mL}$ of $\mathrm{B}-\mathrm{R}$ buffer used in a final $10 \mathrm{~mL}$ solution.

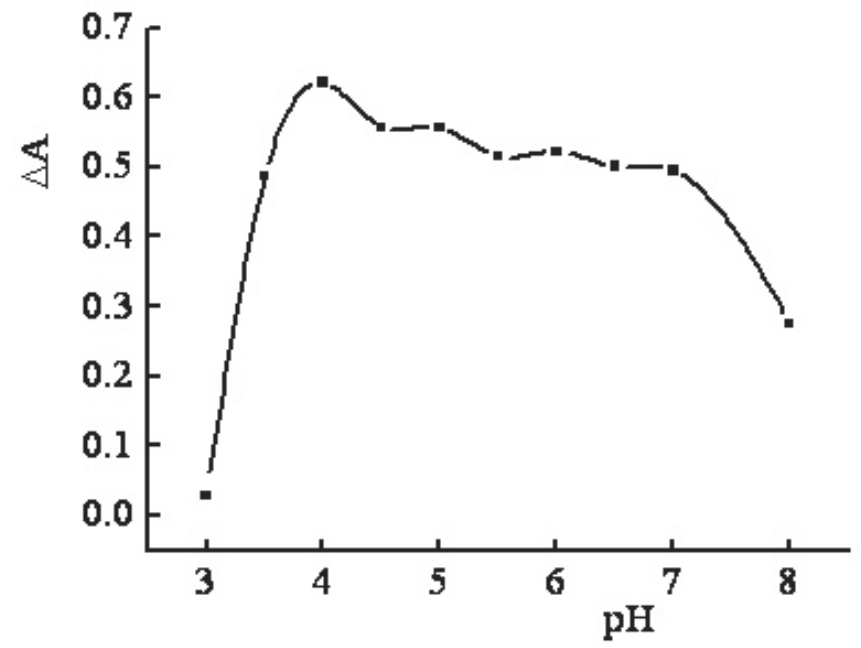

Fig.3: The influence of $\mathrm{pH}$ on the interaction of crystal violet with yRNA B-R of different $\mathrm{pH}+2.0 \times 10^{-5} \mathrm{~mol} \mathrm{~L}^{-1} \mathrm{CV}+3.33 \times 10^{-4} \mathrm{~mol} \mathrm{~L}^{-1}$ yRNA

\section{Effect of $\mathrm{CV}$ concentration}

The effect of the $\mathrm{CV}$ concentration on the binding reaction was examined by fixing yRNA concentration at $100.0 \mathrm{mg} \mathrm{L}^{-1}$. As shown in Figure 4, when the concentration of $\mathrm{CV}$ was at $2.0 \times 10^{-5} \mathrm{~mol} \mathrm{~L}^{-1}$, the difference of absorbance value $(\triangle \mathrm{A})$ reached its maximum, so the final concentration of $\mathrm{CV}$ was fixed at $2.0 \times 10^{-5} \mathrm{~mol} \mathrm{~L}^{-1}$ in this experiment.

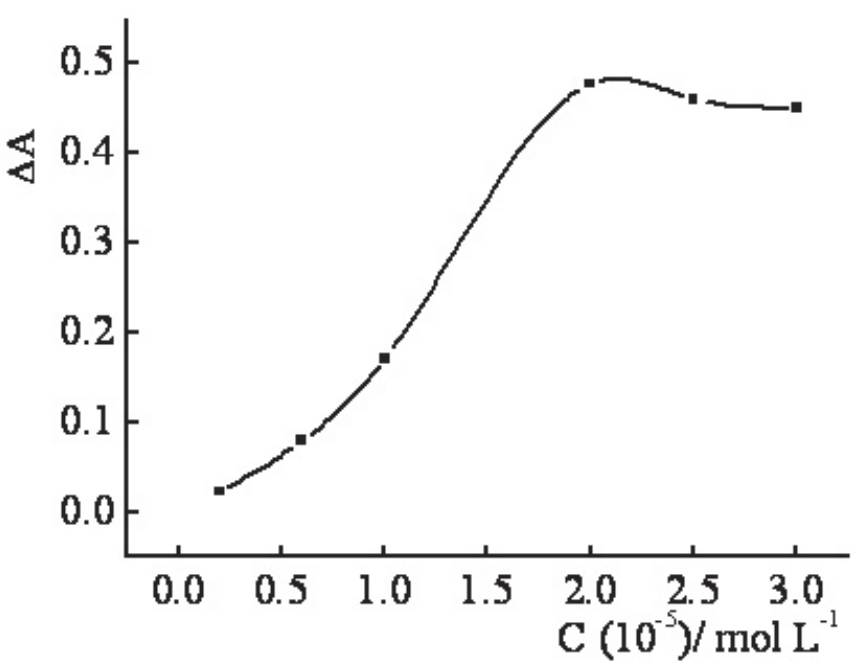

Fig.4: The influence of the concentration of $\mathrm{CV}$ on the interaction pH 4.0 B-R buffer +different concentration of $\mathrm{CV}+3.33 \times 10^{-4} \mathrm{~mol} \mathrm{~L}^{-1}$ yRNA

Reaction time, temperature and stability

The binding reaction occurred quickly at $25^{\circ} \mathrm{C}$ and reached the equilibrium for about $20 \mathrm{~min}$. The absorbance value remained constant for about 1 hour, which indicated that this system was stable enough for the routine application.

Interference of foreign substances

The influences of coexisting substances such as metal ions, amino acids and glucose etc. on the determination of $1.67 \times 10^{-5} \mathrm{~mol} \mathrm{~L}^{-1}$ yRNA were tested and the results were listed in Table 1. Most of these substances had little effect on the determination, so this analytical method had good selectivity. 
Table 1.- Interferences of coexisting substances on the determination of $1.67 \times 10^{-5} \mathrm{~mol} \mathrm{~L}^{-1}$ yRNA $(n=3)$

\begin{tabular}{|c|c|c|c|c|c|}
\hline $\begin{array}{c}\text { Coexisting } \\
\text { substances }\end{array}$ & $\begin{array}{c}\text { Concentration / } \\
(\mathrm{mol} \mathrm{L})\end{array}$ & Relative error / \% & $\begin{array}{c}\text { Coexisting } \\
\text { substances }\end{array}$ & $\begin{array}{c}\text { Concentration / } \\
\left(\mathrm{mol} \mathrm{L}^{-1}\right)\end{array}$ & Relative error / \% \\
\hline $\mathrm{Ca}^{2+}$ & $5.0 \times 10^{-5}$ & -5.55 & Citric acid & $2.38 \times 10^{-5}$ & 1.59 \\
\hline $\mathrm{Fe}^{3+}$ & $5.0 \times 10^{-5}$ & -3.17 & Glycine & $6.67 \times 10^{-5}$ & -5.52 \\
\hline $\mathrm{Cu}^{2+}$ & $5.0 \times 10^{-5}$ & 0.61 & L-Tyrosine & $2.76 \times 10^{-5}$ & -2.45 \\
\hline $\mathrm{Co}^{2+}$ & $5.0 \times 10^{-5}$ & 2.38 & L-Leucine & $3.82 \times 10^{-5}$ & -7.36 \\
\hline $\mathrm{Sn}^{2+}$ & $5.0 \times 10^{-5}$ & -3.49 & L-Cysteine & $4.13 \times 10^{-5}$ & -5.05 \\
\hline $\mathrm{Mn}^{2+}$ & $5.0 \times 10^{-5}$ & 1.23 & L-Glutamine & $3.40 \times 10^{-5}$ & -1.24 \\
\hline $\mathrm{Mg}^{2+}$ & $5.0 \times 10^{-5}$ & 4.90 & L-Arginine & $2.87 \times 10^{-5}$ & 5.52 \\
\hline $\mathrm{Zn}^{2+}$ & $5.0 \times 10^{-5}$ & -6.35 & L-Valine & $4.27 \times 10^{-5}$ & 2.58 \\
\hline $\mathrm{Glucose}^{2+}$ & $2.8 \times 10^{-5}$ & -1.23 & L-Serine & $4.76 \times 10^{-5}$ & -5.87 \\
\hline
\end{tabular}

\section{Calibration curve}

Under the optimal conditions a linear relationship of $\triangle \mathrm{A}$ against the yRNA concentration was established. The linear regression equation was got as $\Delta \mathrm{A}=$ $1.52 \times 10^{-7} \mathrm{C}\left(\mathrm{mol} \mathrm{L}^{-1}\right)+0.0024(\mathrm{n}=7, \gamma=0.998)$ with the concentration range from $3.33 \times 10^{-6}$ to $1.67 \times 10^{-5} \mathrm{~mol} \mathrm{~L}^{-1}$. The relative standard deviation (RSD) of 11 parallel determinations of $6.64 \times 10^{-6} \mathrm{~mol} \mathrm{~L}^{-1}$ yRNA was got as $2.43 \%$. The detection limit $(3 \sigma)$ of this method was given by $3 \mathrm{~S} / \mathrm{S}$ and the result was got as $5.34 \times 10^{-7} \mathrm{~mol} \mathrm{~L}^{-1}$, where 3 is the factor at the $99 \%$ confidential level, $\mathrm{S}_{0}$ is the standard deviation of the black measurements $(\mathrm{n}=11)$ and $\mathrm{S}$ is the slope of the calibration curve. The quantification limit was given by $10 \mathrm{~S}$ and got as $1.52 \times 10^{-6} \mathrm{~mol} \mathrm{~L}^{-1}$ and the determination limit was $3.33 \times 10^{-6} \mathrm{~mol} \mathrm{~L}^{-1}$.

\section{Samples determination}

Synthetic and real samples were detected in order to test the practicability of the proposed method. Three yRNA synthetic samples containing amino acid, metal ions etc. were determined with the proposed method and the results were shown in Table 2. The instant dry yeast samples were further determined with the proposed method by using the standard addition procedure and the results were shown in Table 3. It can be seen that the proposed method was practical and reliable for the sample determination with satisfactory results.

Table 2.- Determination results of yRNA in synthetic samples $(n=5)$

\begin{tabular}{|c|c|c|c|c|c|}
\hline Samples & $\begin{array}{l}\text { Coexisting } \\
\text { substances }\end{array}$ & $\begin{array}{l}\text { Added } \\
/(\mathrm{mol} \\
\left.\mathrm{L}^{-1}\right)\end{array}$ & $\begin{array}{l}\text { Found } \\
/(\mathrm{mol} \\
\left.\mathrm{L}^{-1}\right)\end{array}$ & $\begin{array}{c}\mathrm{RSD} \\
/ \%\end{array}$ & $\begin{array}{c}\text { Recovery } \\
/ \%\end{array}$ \\
\hline 1 & $\begin{array}{l}\text { L-Arginine, L- } \\
\text { Tyrosine, } \mathrm{Zn}^{2+}, \\
\qquad \mathrm{Ca}^{2+}\end{array}$ & $3.33 \times 10^{-6}$ & $3.36 \times 10^{-6}$ & 1.00 & 101.00 \\
\hline 2 & $\begin{array}{l}\text { L-Leucine, L- } \\
\text { Arginine, } \mathrm{Zn}^{2+} \text {, } \\
\mathrm{Co}^{2+}\end{array}$ & $1.00 \times 10^{-5}$ & $1.02 \times 10^{-5}$ & 2.33 & 102.30 \\
\hline 3 & $\begin{array}{l}\text { L-Leucine, } \\
\text { L-Valine, } \mathrm{Mg}^{2+}, \\
\mathrm{Mn}^{2+}\end{array}$ & $1.91 \times 10^{-5}$ & $1.96 \times 10^{-5}$ & 1.00 & 101.00 \\
\hline
\end{tabular}

*Concentration of coexisting substances: L-Arginine: $5.54 \times 10^{-8} \mathrm{~mol} \mathrm{~L}^{-1}, \mathrm{~L}-$ Tyrosine: $5.52 \times 10^{-8} \mathrm{~mol} \mathrm{~L}^{-1}$, L-Leucine: $7.64 \times 10^{-8} \mathrm{~mol} \mathrm{~L}^{-1}$, L-Valine: $8.54 \times 10^{-8}$ $\mathrm{mol} \mathrm{L}{ }^{-1}, \mathrm{Ca}^{2+}, \mathrm{Mn}^{2+}, \mathrm{Mg}^{2+}, \mathrm{Zn}^{2+}, \mathrm{Co}^{2+}: 1.0 \times 10^{-5} \mathrm{~mol} \mathrm{~L}^{-1}$

Table 3.- Determination results of the instant dry yeast samples $(\mathrm{n}=5)$

\begin{tabular}{|c|c|c|c|c|c|}
\hline Samples & $\begin{array}{c}\text { Sample } \\
\text { content } \\
/\left(\mathrm{mol} \mathrm{L}^{-1}\right)\end{array}$ & $\begin{array}{c}\text { Added } \\
/\left(\mathrm{mol} \mathrm{L}^{-1}\right)\end{array}$ & $\begin{array}{c}\text { Found } \\
/(\mathrm{mol} \\
\left.\mathrm{L}^{-1}\right)\end{array}$ & $\begin{array}{c}\text { RSD } \\
/ \%\end{array}$ & $\begin{array}{c}\text { Recovery } \\
/ \%\end{array}$ \\
\hline 1 & $9.224 \times 10^{-7}$ & $8.325 \times 10^{-6}$ & $9.407 \times 10^{-6}$ & 1.79 & 101.92 \\
\hline 2 & $2.604 \times 10^{-7}$ & $8.325 \times 10^{-6}$ & $1.104 \times 10^{-5}$ & 2.07 & 101.28 \\
\hline
\end{tabular}

Stoichiometry of CV and yRNA complex

The binding number of $\mathrm{CV}$ with yRNA unit was obtained by the molar ratio method. The relationship between the absorbance value and the concentration of yRNA was shown in Figure 5. The absorbance value became stability when the concentration of yRNA was big enough. The point of inter section of these two lines was got at the yRNA concentration as $\mathrm{C}_{\mathrm{yRNA}}=1.94 \times 10^{-5} \mathrm{~mol} \mathrm{~L}^{-1}$, hence the molar ratio between $\mathrm{CV}$ and yRNA unit was got as $\mathrm{Nc}=\mathrm{C}_{\mathrm{CV}} / \mathrm{C}_{\mathrm{yRNA}} \approx 1$.

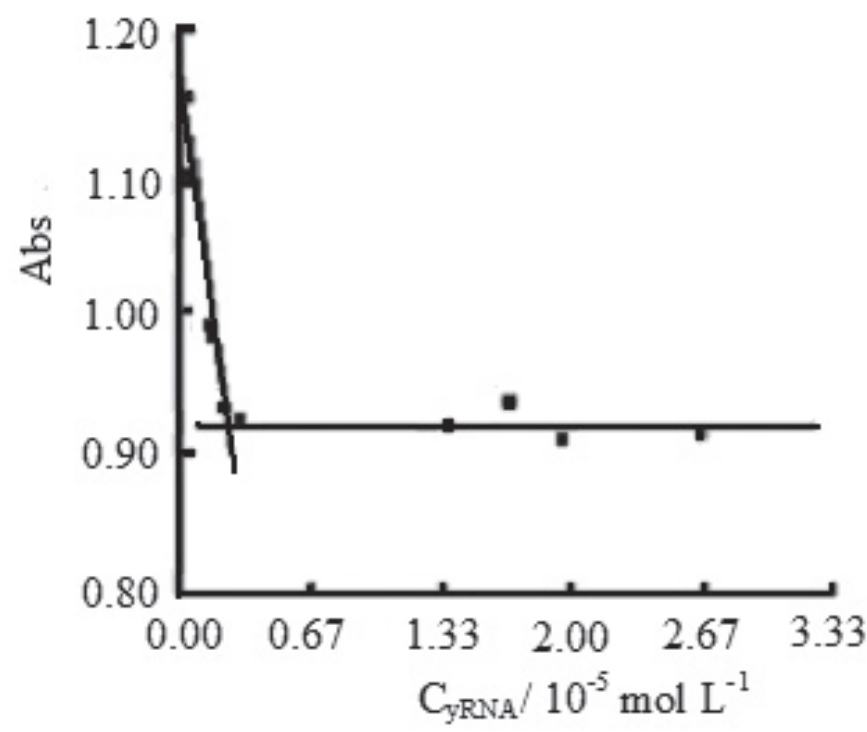

Fig.5.- Determination of binding number of CV-yRNA complex by molar ratio method

$\mathrm{pH}$ 4.0 B-R buffer $+2.0 \times 10^{-5} \mathrm{~mol} \mathrm{~L}^{-1} \mathrm{CV}+$ different amount of yRNA

The binding constant $\mathrm{K}_{\mathrm{f}}$ was further determined with the following equation: ${ }^{19,20}$

$$
\frac{A_{0}}{A_{-}-A_{0}}=\frac{\varepsilon_{G}}{\varepsilon_{H-G}-\varepsilon_{G}}+\frac{\varepsilon_{G}}{\varepsilon_{H \cdot G}-\varepsilon_{G}} \frac{1}{K_{f}[R N A]}
$$

where $\mathrm{A}_{0}$ and $\mathrm{A}$ are the absorbance value of the free guest and the apparent one, $\varepsilon_{\mathrm{G}}$ and $\varepsilon_{\mathrm{H}-\mathrm{G}}$ are the absorption coefficients of the guest and the complex, respectively.

By changing the concentration of yRNA in $\mathrm{CV}$ solution, the absorbance value was obtained and the relationship of $A_{0} /\left(A-A_{0}\right)$ with $1 /[y R N A]$ was plotted. From the equation $\mathrm{A}_{0} /\left(\mathrm{A}-\mathrm{A}_{0}\right)=3.74 \times 10^{-5} /[\mathrm{yRNA}]-6.17$, the ratio of the intercept to the slope gave the value of the binding constant $\left(\mathrm{K}_{\mathrm{f}}\right)$ as $1.65 \times 10^{5}$ $\mathrm{L} \mathrm{mol}^{-1}$.

The schematic presentation of the interaction between yRNA and CV 
could be illustrated in Figure 6 and the interaction mechanism was further discussed. In the selected acidic solution of pH 4.0, the CV molecules were in positively charged, while the deprotonation of phosphate group induced a negative charge in the yRNA chains. So the electrostatic attraction led to the molecular association of CV with yRNA.<smiles>CC[C+](=C1C=CC(=C(c2ccc(C)cc2)c2ccc(N(C)C)cc2)CC1)N(C)CC</smiles>

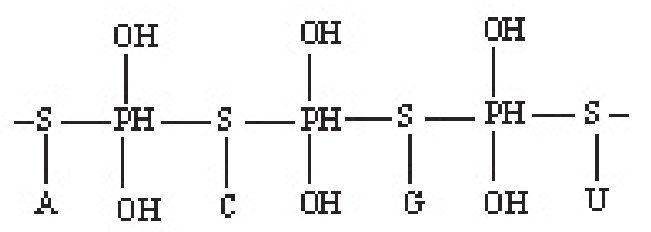<smiles>CCCCN(C)c1ccc(C(=C2C=CC(=[NH+]C)C=C2)C2CCCCC2)cc1</smiles><smiles>CS[Pb]([O-])([O-])SS(=O)(=O)S(=O)(=O)[O-]</smiles>

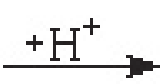<smiles>C[C+]C</smiles><smiles>CS[Sn]([O-])([O-])S(=O)(=O)S[Sb](=O)([O-])SC</smiles><smiles>CCCCNc1ccc(C(=C2C=CC(=NC)C=C2)C23CCC(CC2)CC3)cc1</smiles>

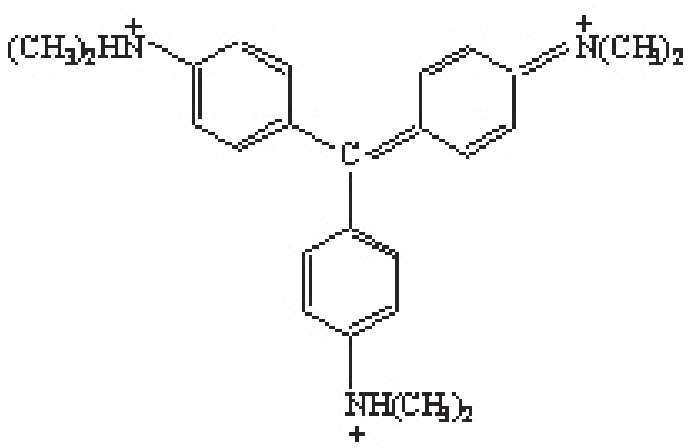

Fig. 6.- The schematic presentation of the interactions between yRNA and CV

\section{CONCLUSION}

In this paper the interaction of CV with yRNA was studied by UV-Vis spectrophotometric method. The results showed that a 1:1 biocomplex was formed with the binding constant as $1.65 \times 10^{5} \mathrm{~L} \mathrm{~mol}^{-1}$. The interaction conditions such as the buffer $\mathrm{pH}, \mathrm{CV}$ concentration, reaction time and temperature etc. were carefully investigated. Under the optimal conditions, a simple and sensitive spectrophotometric method for yRNA detection was established and successfully applied to the samples determination. 
2. E. C. Long, J. K. Barton, Acc. Chem. Res. 23, 271, (1990).

3. W. Chen, N. J. Turro, D. A. Tomalia, Langmuir. 16, 15, (2000).

4. L. Jin, P. Yang, Q. S. Li, Chem. Res. Chin. Univ. 17, 1345, (1996).

5. C. Z. Huang, K. A. Li, S. Y. Tong, Anal. Chem. 69, 514, (1997).

6. F. Gao, Y. X. Li, L. Zhang, L. Wang, Spectrochim. Acta. A. 60, 2505, (2004).

7. M. Aslanoglu, Acta Chim. Slov. 51, 107, (2004).

8. W. Sun, J. Y. You, X. Hu, K. Jiao, Anal. Sci. 22, 693, (2006).

9. H. Xu, H. Deng, H. Y. Hu, J. Z. Liu, H. Chao, J. Liu, L. N. Ji, Chem. J. Chin. Univ. 24, 25, (2003).

10. W. Sun, J. Y. You, X. Hu, K. Jiao, Anal. Lett. 39, 33, (2006).

11. D. T. Breslin, G. B. Schuster, J. Am. Chem. Soc. 118, 2311, (1996).
12. Z. Balcarova, V. Brabec, Biophys. Chem. 33, 55, (1989).

13. P. J. Cater, C. C. Cheng, H. H. Thorp, J. Am. Chem. Soc. 120, 632, (1998).

14. M. Lindell, P. Romby, E. G. Wagner, RNA 8, 534, (2002).

15. C. S. Chwo, J. K. Barton, Biochemistry 31, 5423, (1992).

16. A. C. Liu, J. K. Barton, Biochemistry 37, 9138, (1998).

17. F. Chu, J. Smith, M. Lynchv, E. V. Anslyn, Inorg. Chem. 34, 5689, (1995).

18. W. Sun, J. Y. You, Q. X. Wang, K. Jiao, Chem. Anal. 51, 477, (2006).

19. M. S. Ibrahim, Anal. Chim. Acta. 443, 63, (2001).

20. M. S. Ibrahim, I. S. Shehatta, A. A. Al-Nayeli, J. Pharm. Biomed. Anal. 28, 217, (2002). 